\title{
Garbage Management Policy in the Regency of Banyumas, Central Java, Indonesia
}

\author{
Chafid Diyanto ${ }^{1}$, Hardi Warsono ${ }^{2}$ \\ \{chafiddiyanto@students.undip.ac.id ${ }^{1}$,hardie_wsn@live.undip.ac.id²\} \\ Universitas Diponegoro, Indonesia ${ }^{1,2}$
}

\begin{abstract}
Garbage has become a critical problem in Indonesia and even in the world, including in Banyumas Regency. This study aims to see how the garbage management policy in the Regency of Banyumas. Garbage management that is still conventional is limited to collecting and moving or disposing of it to the Final Disposal Site (FDS) is only a temporary handling of waste that will only create a time bomb. It is still warm in the minds of Banyumas people how the effect is caused by the rejection of the community around the Gunung Tugel FDS and Kaliori FDS at the end of 2018 . Nearly 4 months the community was confused about disposing of garbage. Because the temporary garbage shelters have been overloaded, which in turn is closed by the surrounding community. As a result, in almost every corner of the Banyumas Regency, especially in Purwokerto, piles of rubbish can be found and the environment becomes dirty. To overcome this problem, the relevant agencies issue a policy on independent waste management. However, it is unfortunate that the policy seems rushed and has many shortcomings, including: the policy is top down and does not involve public participation; quick and brief policy socialization; reactive and short-term policies.
\end{abstract}

Keywords: Garbage, Policy.

\section{Introduction}

Garbage has become a critical problem in Indonesia and even in the world, including in Banyumas Regency. Garbage management is still, limited to collecting and moving or disposing it to the Final Disposal Site (FDS) is only temporary handling of garbage that will only create a time bomb that will explode in the future. It is still warm in the minds of the Banyumas people how the effect is caused by the rejection of the community around the Gunung Tugel FDS and Kaliori FDS at the end of 2018 yesterday. Nearly 4 months the community was made confused where they should throw garbage. Because the temporary garbage shelters have been overloaded, which in turn is closed by the surrounding community because it is already disturbing.

As a result, in almost every corner of the Banyumas Regency area, especially in Purwokerto area, piles of garbage can be found lying dormant, scattering and making the environment dirty. At that time, in order to overcome this problem, the Regional Government through the relevant agencies issued a policy on independent or self-managed garbage management. Through the District Circular Letter numbered 660.1/7776/2018, garbage management which originally used the collection, transport and disposal patterns to the FDS, changed with the pattern of garbage management starting from the source. 
Through this pattern, the community is asked to sort out the garbage generated themselves, utilize garbage that can be used, and destroy the remaining unused garbage. Whereas for people who cannot process garbage, they are asked to collaborate with NGG (Non-Governmental Groups) that manage hangars in IGMS (Integrated Garbage Management Sites). Through this pattern change, the district government no longer deals with the waste problem, because it has been approved by the NGG. Likewise, the FDS that has been managed by the Banyumas Regency Government through the Department of the Environment (DLH) no longer exists.

But it is unfortunately that the policy seems rushed and many have shortcomings. The garbage management policy through self-management by the community also raises the perception as if the local government wants to get out of hand and run away from its responsibilities as a policy holder.

This garbage management policy should really be well-formulated and mature. Community involvement is certainly needed, because in addition to being able to produce the right policies, it can also raise public awareness of the importance of garbage management.

\section{Research Method}

This type of research is a descriptive qualitative research with data collection techniques, namely interviews, observation and documentation. The data validity checking is done through triangulation and member check. Data analysis techniques using data condensation, data presentation, and drawing conclusions.

\section{Result and Discussion}

\subsection{Understanding Public Policy}

According to Anderson policy can be interpreted as a series of actions that have certain objectives that are followed and implemented by a person or group of actors to solve a particular problem [1]. Policies can be done in general, but in fact more often and widely used in the actions or behavior of government and state behavior in general, better known as state policy or public policy.

While the definition of public or state policy itself is also defined differently by experts, as stated by Dye [1] that state policy as "is whatever the government chooses to do or not to do". Dye further said that if the government chooses to do something there must be a purpose and be objective and include all government actions.

Edward and Sharkansky [1] said that state policy namely "is what government says and do, or not do, it is the goals or purposes of government programs" (is what is stated and done or not done by the government, policy the country is in the form of goals or objectives of government programs). Public Policy is: a reaction to real world needs or problems. Public policy seeks to react to the concrete needs or problems of a society or groups within a society, e.g., citizens, non-governmental organizations (NGOs) or government bodies [2].

Based on the above understanding, however, the formulation is basically the state policy leading to the public interest, taking into account the existing values. Therefore, the state policy can be concluded as a series of actions taken or not taken by the government, whether 
carried out by a person or group of people to achieve a certain goal oriented to the interests of the community. Based on the understanding of public policies and policies outlined above, Islamy stated several important elements of state policy, namely: a. That the State's policy in the form of it's in the form of the establishment of government actions; b. State policy is not enough to simply be stated but implemented in a tangible form; c. Policies to do or not do something needs to be based on certain goals and objectives; $d$. State policy must be aimed at the interests of society [1].

Public policy is an ongoing process, because what is most important is the policy cycle. The policy cycle includes the formulation, implementation and evaluation of policies [3]. Policies that have been formulated or formulated intend to achieve certain objectives. In this context it is understandable, that the policy will not be successful, if the implementation has nothing to do with the objectives set. Often there is an assumption after the policy is ratified by the authorities that the policy will automatically be implemented, and the results will approach as expected by the policy maker. Whereas in the public policy process that will be implemented, it must go through a process / stage that is quite long.

Furthermore, according to [4] dimensions that can be used to evaluate the implementation of public policies include: consistency, transparency, accountability, fairness, effectiveness, and efficiency.

\subsection{Garbage Management Policy in Banyumas Regency}

Referring to the definition of public policy above, then a policy must go through a process of formulation that is done first with an assessment of various policy options, including garbage management policies.

Garbage has become a critical problem in Indonesia and even in the world, including in Banyumas Regency. This certainly requires an appropriate garbage management policy. Based on data from the Department of the Environment (DLH), Banyumas Regency, which has a population of around 2 million people, is estimated to produce 600 tons of garbage every day assuming that each resident produces 0.3 kilograms per day. And of that amount, only 45 percent or about 270 tons of garbage per day can be transported by DLH to be disposed of in FDS. The rest, some are entering the recycling industry, collectors, garbage banks, Integrated Garbage Management Sites (IGMS), and the community directly around 15 percent or 60 tons, into compost about 5 percent or 30 tons, and other 35 percent or around 200 tons are not managed.

From the data above, there are around 80 percent of garbage or 470 tons of garbage per day that has not been utilized and must be destroyed. Garbage management that is still conventional in nature is limited to collecting and moving or disposing it to the Final Disposal Site (FDS) is only temporary handling of garbage that will only create a time bomb that will explode in the future. It is still warm in the minds of the people of Banyumas Regency how the effect is caused by the rejection of the community around the Gunung Tugel FDS and Kaliori FDS at the end of 2018 yesterday. Nearly 4 months the community was made dizzy and confused where they should throw garbage. Because the temporary garbage shelters have been overloaded, which in turn is closed by the surrounding community because it is already disturbing comfort. As a result, in almost every corner of the Banyumas Regency, especially the Purwokerto City area, piles of garbage can be found lying dormant, scattering and making the environment dirty. At that time, in order to overcome this problem, the Regional Government through the relevant agencies issued a policy on independent or self-managed garbage management. Through the District Circular Letter numbered 660.1/7776/2018, 
garbage management which originally used the collection, transport and disposal patterns to the FDS, changed with the pattern of garbage management starting from the source. In a circular it was stated that starting on January 2, 2019 there was a change in the pattern of garbage management in Banyumas Regency from the one previously based on services by the regional government, namely by the pattern of collection, transportation, and disposal to the landfill.

Through this pattern, the community is asked to sort out the garbage generated themselves, utilize garbage that can be used, and destroy the remaining unused garbage. Whereas for people who cannot process garbage, they are asked to collaborate with the KSM (Community Self-Help Group) which manages the hangar at TPST (Integrated Garbage Management Site).

According to the Head of DLH Banyumas Regency Suyanto [5] the meaning of garbage management at its source is the garbage generated from sources of garbage generation including households, area managers, retailers, markets, hotels, restaurants, agencies, and offices then sorting, exploiting, and destroying the rest at the original location so that there is no garbage disposal. Suyanto said if the source of garbage producers cannot manage it, it can work together with the NGG garbage management in their respective regions by paying fees the amount according to the agreement with the local NGG.

Banyumas District Government itself in 2018 has built a garbage sorting hangar which is used as a garbage management center for garbage producers who cannot manage it at its source. Banteran Village (Wangon Sub-District), Karangcegak Village (Sumbang SubDistrict), Kedungrandu Village (Patikraja Sub-District), and Kradenan Sub-District (Sumpiuh Sub-District), while the management is carried out by NGG who have received training.

With the pattern of garbage management being carried out directly from the source of the garbage producer, the Banyumas Regency Government starting on January 2 no longer carries out the garbage from the source of the garbage producer and does not collect levies on the garbage service, leaders of vertical agencies, leaders of regional apparatus organizations, and leaders of BUMN/BUMD to be able to carry out garbage management from their source in their respective offices or cooperate with local NGG in managing their garbage. In addition, the sub-district heads are asked to order village heads in their areas. In order to inform their citizens to manage garbage from its source.

But it is unfortunate that the policy seems rushed and many have shortcomings, including:

\subsubsection{Policies are top down and do not involve public participation}

Policy formulation is the earliest step in the overall public policy process. Therefore what happens in this phase will determine the success or failure of the public policy made in the future [6]. A public policy will be more easily accepted by the community when it is implemented when the formulation of the public policy is bottom up by involving public participation. The community will feel involved and have a sense of responsibility to participate in the success of these public policies.

Community participation is the involvement and participation of the community in implementing policies. Community participation besides supporting the acceleration of policy implementation, on the other hand will have an impact on the process of evaluating or controlling government performance and being able to minimize the abuse of authority. Community participation is the key to success in implementing public policies because participation involves aspects of supervision and aspirations [4]. 
In addition to official policy makers, there are also other participants involved in the policy process which include interest groups; political parties; research organization; communication media; as well as community individuals. These are called non-governmental participants (non-governmental participants) because of their important or dominant role in a number of policy situations, but they do not have legal authority to make binding policies [6].

This is very different if the public policy is top down, without involving community participation from the beginning of its formulation. Society will tend to be passive even sometimes due to lack of socialization can lead to misperceptions and even friction between the community and the local government as a policy maker.

This condition seems to occur in the process of formulating garbage management policies in Banyumas Regency. The change in the garbage management system has become a polemic among the people, especially in urban communities. Many residents in the housing and business world are confused because garbage collectors who previously worked to collect their garbage, are no longer working [7].

\subsubsection{Quick and brief policy socialization}

The socialization of a public policy is very important, so that the public truly understands and shares a perception with the local government as a policy maker. Policy socialization certainly takes a short time, and it should be done since the policy was formulated by involving public or community participation. When a policy is formulated without involving community participation and outreach to the community which is quick and brief, it can be ensured at the implementation level that it will not run well. This is what happened in the garbage management policy issued by the Banyumas Regency Government. In the midst of the community's confusion about the garbage problem, suddenly there is a policy that actually makes people more confused. As complained by Toto Suryo as the manager of a restaurant in the city of Purwokerto [8] that he claimed to be confused with the policies of the Banyumas Regency Government regarding the implementation of garbage management from its source.

Anxiety was also felt by the urban community, as conveyed by Indri, a resident of West Purwokerto Subdistrict to the author, that he was confused about where to throw garbage, because the usual TPS to dispose of garbage has been closed by residents.

\subsubsection{Policies that are reactive and short term}

Making or formulating policies is not a simple and easy process. This is due to many factors or forces that influence the policy making process [6]. A public policy must be formulated thoroughly through various studies in order to solve public problems without causing other public problems or minimizing the emergence of new problems. Public Policies are goal oriented. Public policies are formulated and implemented in order to attain the objectives which the government has in view for the ultimate benefit of the masses in general. The policy proposals clearly spell out the programs of government [9].

The garbage management policy in Banyumas Regency tends to be reactive and shortterm is only limited to overcome the rejection of residents around the TPA. This is increasingly proven when some of the landfills are able to function again and there is no more accumulation of garbage in the TPS, the self-managed garbage management policy is as if forgotten and unsustainable. 


\section{Conclusion}

Garbage has become a problem in the world, including in Banyumas Regency, Central Java, Indonesia. In dealing with this garbage problem, it is necessary to formulate an appropriate, planned and sustainable garbage management policy. Do not let public policies made precisely cause new problems and confuse the public. As with the garbage management policy made by the Banyumas District Government which has been in its formulation to the stage of its implementation has several weaknesses, namely: (1) The policy is top down and does not involve public participation; (2) quick and brief policy socialization; (3) Policies that are reactive and short term.

Garbage management policy set forth in the Regent's Circular Letter numbered $660.1 / 7776 / 2018$ on Garbage Management in Banyumas Regency is actually good because previously the garbage management was carried out at the end of the garbage collection process and then diverted from the beginning from the source and actively involved the community in garbage management. Therefore, in order to improve some of the existing weaknesses, it is necessary to immediately take a number of concrete steps by the Banyumas District Government, namely: (1) Conducting a massive and measurable socialization to all stakeholders and levels of society related to the Regent's Circular Letter; (2) In the implementation phase of the garbage management policy, it must remain willing to accept and follow up on the aspirations of the community, among others related to the limitations of supporting infrastructure; (3) Immediately formulate measurable and sustainable policy plans and targets through a definite budget policy.

\section{References}

[1] I. Islamy, Prinsip-prinsip perumusan kebijaksanaan negara. Bumi Aksara, 1997.

[2] E. Young and L. Quinn, "Writing effective public policy papers," Open Soc. Institute, Budapest, 2002.

[3] W. Parsons, Public Policy: An Introduction to the Theory and Practice of Policy Analysis The Fast Free Shipping. Edward Elgar Publishing Ltd, 1995.

[4] A. Ramdhani and M. A. Ramdhani, "Konsep umum pelaksanaan kebijakan publik,” J. Publik, vol. 11, no. 1, pp. 1-12, 2017.

[5] Sumaworto, "Banyumas segera miliki pusat daur ulang sampah," Antara News, 2018. [Online]. Available: https://jateng.antaranews.com/berita/207463/banyumas-segera-miliki-pusat-daurulang-sampah.

[6] M. H. Ismail and A. Sofwani, "Konsep dan Kajian Teori Perumusan Kebijakan Publik," J. Rev. Polit., vol. 6, no. 2, pp. 195-224, 2016.

[7] E. Widiyatno, "Perubahan Sistem Pengelolaan Sampah di Banyumas Jadi Polemik," Republika, 2019. [Online]. Available: https://www.republika.co.id/berita/nasional/daerah/19/01/07/ pkynhv399-perubahan-sistem-pengelolaan-sampah-di-banyumas-jadi-polemik .

[8] A. Nugraha, "Warga Tak Paham Aturan Swakelola, Banyumas Banyak Tumpukan Sampah," detiknews, 2019. [Online]. Available: https://news.detik.com/berita-jawa-tengah/d4374395/warga-tak-paham-aturan-swakelola-banyumas-banyak-tumpukan-sampah.

[9] P. Raj, Public Policy. Ray University, India, 1976. 